\title{
Exposure to endocrine disrupting chemicals and male reproductive health
}

\author{
Hueiwang Anna Jeng* \\ School of Community and Environmental Health, College of Health Sciences, Old Dominion University, Norfolk, VA, USA
}

Edited by:

Efstratios Gregory Vogiannis,

Evangeliki Model School of Smyrna,

Greece

Reviewed by:

Olga loanna Kalantzi, University of the

Aegean, Greece

Christodoulos D. Makedonas,

National and Kapodistrian University

of Athens, Greece

*Correspondence:

Hueiwang Anna Jeng, School of Community and Environmental

Health, College of Health Sciences, Old Dominion University, Health

Sciences Building Room 3140, 4608

Hampton Boulevard, Norfolk, VA

23529, USA

e-mail: hjeng@odu.edu
Endocrine disrupting chemicals (EDCs) can interfere with normal hormonal balance and may exert adverse consequences on humans. The male reproductive system may be susceptible to the effects of such environmental toxicants. This review discusses the recent progress in scientific data mainly from epidemiology studies on the associations between EDCs and male reproductive health and our understanding of possible mechanisms associated with the effects of EDCs on male reproductive health. Finally, the review provides recommendations on future research to enhance our understanding of EDCs and male reproductive health. The review highlights the need for (1) well-defined longitudinal epidemiology studies, with appropriately designed exposure assessment to determine potential causal relationships; (2) chemical and biochemical approaches aimed at a better understanding of the mechanism of action of xenoestrogens with regard to low-dose effects, and assessment of identify genetic susceptibility factors associated with the risk of adverse effects following exposure to EDCs.

Keywords: endocrine disruptors, bisphenol A, phthalates, polychlorinated biphenyls, dichlorodiphenyltrichloroethane, dichlorodiphenyldichloroethylene

\section{INTRODUCTION}

Endocrine disrupting chemicals (EDCs) are estrogen-like and/or anti-androgenic compounds that disrupt and interfere with the production, release, transport, metabolism, binding, or elimination of natural hormones in the body responsible for the maintenance of homeostasis and the regulation of developmental processes (1). EDCs include persistent pesticides and herbicides, methoxychlor, biocides, heat stabilizers, and chemical catalysts, plastic contaminants, pharmaceuticals, or dietary components. Those exogenous compounds can arise from industrial and domestic effluents or agricultural and urban runoff. The general population continues to be exposed to EDCs through ingestion of contaminated food, inhalation of contaminated air and dust, and skin contact, while some areas are subjected to greater risk due to geographical and cultural reasons (2). Due to temporal downward trends in semen quality and testosterone levels and increased rates of testicular cancers among adult male populations $(3,4)$, scientific researchers, and the general public have become increasingly concerned regarding the potential risk of EDCs to men's reproductive health. Cellular models and animal toxicological studies have demonstrated that EDCs can exert adverse effects on the male reproductive system. In humans, there are a growing number of epidemiological studies about EDCs and detrimental reproductive function. However, a potential decline in human male reproductive health and a link to exposure to endocrine active chemicals in the environment has been controversial for almost two decades. This article focuses on the review of the human data regarding the relationship between exposures to known or suspected EDCs. It specifically focuses on bisphenol A (BPA), phthalates, polychlorinated biphenyls (PCBs), and dichlorodiphenyltrichloroethane
(DDT)/dichlorodiphenyldichloroethylene (DDE) and men's semen quality, sperm DNA damage, reproductive hormone levels, and reproductive diseases. This review provides: (1) an introduction to several common EDCs and their sources, (2) an overview of the state of the human evidence for adverse impacts of EDCs on male reproductive health, and (3) a description of possible mechanisms of action for EDCs involved with detrimental male reproductive functions based on in vitro and in vivo studies, and (4) recommendations for future research needed to enhance our understanding of the effect of EDCs on male reproductive health.

\section{ENDOCRINE DISRUPTORS}

Polychlorinated biphenyls are a class of synthetic chlorinated compounds, which have been recognized as EDCs. PCBs were used in industrial and consumer products such as transformers and hydraulic fluids, and as an additive in paints, oils, and building materials. The use and production of PCBs have been banned since the 1970s, however, there has been no decrease or a slight decrease in the environment since the middle of 1990s (5). There is still considerable health risk from human exposure to PCBs from consumption of contained foods (6).

Dichlorodiphenyltrichloroethane and its main metabolite $\left(p, p^{\prime}-\mathrm{DDE}\right)$ is a widespread, persistent environmental contaminant (7). Technical grade DDT is a mixture of $p, p^{\prime}$-DDT (85\%), $o, p^{\prime}$-DDT (15\%), and $o, o^{\prime}$-DDT (trace amounts). Both $p, p^{\prime}$ DDT and $o, p^{\prime}$-DDT promote estrogenic activity (8). Reproductive abnormalities attributed to DDT/DDE exposure have been reported in a variety of wildlife animals $(9,10)$ and in laboratory rats (11). Epidemiological studies have recently addressed the link between exposure to DDT and male reproductive health (12-15). 
Bisphenol A has been extensively used in production of polycarbonate plastic, epoxy resin, food packaging, and lacquers for food cans. Human beings are primarily exposed to BAP via dietary ingestion of leachings from the inner lining of cans and microware containers during heating of food materials and via beverages in polycarbonate bottles due to repeated usage or contact with any acid/alkaline (16). BPA is prevalent in our environment and measurable levels have been detected in the majority of individuals. Estrogenic activity of BPA was confirmed and is the basis for the recognition of the compound as a known endocrine disruptor.

Phthalates are ubiquitous industrial chemicals that are reported to adversely affect human reproductive outcomes. They are divided into two distinct groups based on molecular weight and with very different applications, toxicological properties, and classification: high molecular weight compounds (di-2-ethylhexyl phthalate with alkyl chain lengths from 8 to 13 carbons) and low molecular weight compounds [diethyl phthalate, dibutyl phthalate (DBP)]. Phthalates also include three di-(2-ethylhexyl) phthalate (DEHP) metabolites, mono-(2-ethylhexyl) phthalate (MEHP) and two oxidative metabolites, mono-(2-ethyl-5-hydroxyhexyl) phthalate (MEHHP), and mono-(2-ethyl-5-oxohexyl) phthalate (MEOHP). High molecular weight phthalates are primarily used as plasticizers in the manufacture of flexible vinyl plastic which, in turn, is used in consumer products, flooring and wall coverings, and medical devices (17). Low molecular weight phthalates are used in personal-care products as solvents and plasticizers for cellulose acetate. Exposure through ingestion, inhalation, and dermal contact are considered important routes of exposure for the general population. Upon exposure, phthalates are rapidly metabolized and excreted in urine and feces (17). Measurement of urinary concentrations of phthalate metabolites has been used as the most common biomonitoring approach for investigating human exposure to phthalates.

\section{ASSOCIATIONS BETWEEN EDCS AND SEMEN QUALITY}

The testicle seems to be an important target organ for PCBs, which can disrupt sperm production and development (18). PCBs had a consistent, significant inverse association with sperm motility, while its relationship with sperm concentration was less inconsistent (Table 1). An association with lower sperm concentrations likely occurred only at higher PCB concentrations. Men who had serum PCB levels of $240 \mathrm{ng} / \mathrm{g}$ lipid and partners diagnosed with an inability to conceive a pregnancy were associated with lower

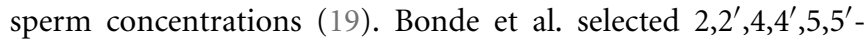
hexachlorobiphenyl (CB-153) as a marker of PCB congeners and found that the non-coplanar PCB congeners only affected sperm motility, whereas the coplanar dioxin-like PCB congener CB-77 also reduced sperm counts (20).

The available epidemiological evidence suggests that exposure to high DDT concentrations has links to semen quality (Table 1). The studies in malaria-endemic areas, where DDT was sprayed consistently, show an association between higher serum DDT concentration and decreased semen quality $(13,33)$. However, such associations were not found in studies conducted in populations where DDT/DDE concentrations were lower. DDT/DDE negatively impacted sperm motility, morphology, count, and semen volume in a South African population of 311 young males living in a malaria area in the Limpopo Province (33). Other studies also observed that DDT exposure adversely affected sperm quality, mainly through decreased motility (12-15). DDT can negatively affect sperm quality, especially when high concentration levels are considered.

Various animal models of BPA exposure have shown multiple effects on the male reproductive system, including inhibition of the development of seminiferous tubules and spermatogenesis, and impaired semen quality $(43,44)$. Increasing evidence from epidemiological studies has revealed the relationship between exposure to BPA and sperm quality, however, that relationship seemingly occurs at high concentrations of BPA exposure. BPA concentration at $1.55 \mathrm{ng} / \mathrm{mL}$ in male partners of sub-fertile couples may influence sperm count (31) based on a reverse relationship between BPA concentration and sperm count. A cross-sectional study performed on a population of 20 healthy men showed that serum BPA level positively correlated with quick forward progression of sperm and was inversely correlated with the percentage of normal sperm (45). In a recent study of 360 fertile men, Mendiola et al. demonstrated that no correlation existed between urinary BPA levels and semen quality, while BPA was inversely correlated with free androgen index concentrations (28). Meeker et al. recorded a similar finding showing a non-significant trend of increasing BPA levels related to lower sperm concentration, motility, morphology, and higher levels of DNA damage (27). A follow-up study on 190 male partners attending an infertility clinic showed that urinary BPA concentration were not associated with semen quality parameters, but they were positively associated with sperm DNA damage (38).

Toxicological studies have consistently shown that phthalate metabolites are reproductive and developmental toxicants. There is evidence that pubertal and adult exposure to DEHP results in testicular toxicity and impaired spermatogenesis $(46,47)$. In the past decade, an increasing number of epidemiological studies have investigated associations between phthalate metabolites and semen quality, but results have not been consistent. One of the first studies investigated 168 men from sub-fertile couples and concluded that specific phthalate metabolites correlated with lower sperm concentration and motility. There were doseresponse relations between mono-butyl phthalate (MBP) and semen quality (motility and concentration), but limited evidence existed for such relations between other phthalate metabolites and poor sperm morphology and concentration (23). In a follow-up study with emphasis on sperm motion parameters, the authors reported that monobenzyl phthalate $(\mathrm{MBzP}), \mathrm{MBP}$, and MEHP have associations with velocity, while no relationship was found for mono-methyl phthalate (MMP) and any sperm motion parameter (48). A recent re-analysis of their data with 463 men again found significant dose-response associations between MBP concentration and low sperm concentration and low motility (24). A recent study of 344 men who had normal semen concentration of $20-300 \times 10^{6} / \mathrm{mL}$ showed that urinary phthalate metabolites [5OH-MEHP, MEHP, mono-isobutyl phthalate (MiBP)] levels were significantly associated with a decrease in sperm motility (26). Weak associations between exposure to phthalate metabolites and lower sperm concentration, motility and morphology in adults have been reported by several studies $(24,25,48,49)$; at 
Table 1 | Epidemiological studies on semen quality and endocrine disruptors including phthalates, BPA, PCB, and DDT/DDE.

\begin{tabular}{|c|c|c|c|c|c|c|}
\hline Compound & Study design & Sample size and subjects & Age & Concentration & Semen quality & First author (year) \\
\hline \multicolumn{7}{|c|}{ PHTHALATE } \\
\hline DEP & Cross-sectional & 300 Healthy males & 29 & $0.64-3.11 \mu \mathrm{g} / \mathrm{mL}$ & $\downarrow$ Concentration & Pant et al. (21) \\
\hline DBP & Cross-sectional & 300 Healthy males & 29 & $0.18-1.65 \mu \mathrm{g} / \mathrm{mL}$ & $\begin{array}{l}\downarrow \text { Concentration, } \\
\text { motility }\end{array}$ & Pant et al. (21) \\
\hline MEP & Cross-sectional & $\begin{array}{l}168 \text { Male partners of } \\
\text { sub-fertile couples }\end{array}$ & 36 & $175.5 \mathrm{ng} / \mathrm{mL}$ & No relationship & Duty et al. (23) \\
\hline MEP & Cross-sectional & $\begin{array}{l}463 \text { Male partners of } \\
\text { sub-fertile couples }\end{array}$ & 36 & $180 \mathrm{ng} / \mathrm{mL}$ & No association & Hauser et al. (24) \\
\hline MEP & Cross-sectional & 269 Male from infertility clinic & 32 & $153.6 \mu \mathrm{g} / \mathrm{mL}$ & No relation & Jurewicz et al. (26) \\
\hline MBP & Cross-sectional & $\begin{array}{l}168 \text { Male partners of } \\
\text { sub-fertile couples }\end{array}$ & 36 & $16.1 \mathrm{ng} / \mathrm{mL}$ & $\begin{array}{l}\downarrow \text { Concentration, } \\
\text { motility, morphology }\end{array}$ & Duty et al. (23) \\
\hline MBP & Cross-sectional & $\begin{array}{l}463 \text { Male partners of } \\
\text { sub-fertile couples }\end{array}$ & 36 & $17.3 \mathrm{ng} / \mathrm{mL}$ & $\begin{array}{l}\downarrow \text { Concentration, } \\
\text { motility }\end{array}$ & Hauser et al. (24) \\
\hline MBP & Cross-sectional & $\begin{array}{l}45 \text { Male partners of sub-fertile } \\
\text { couples }\end{array}$ & 35 & $26.9 \mathrm{ng} / \mathrm{mL}$ & No association & Wirth et al. (25) \\
\hline MBP & Cross-sectional & $\begin{array}{l}269 \text { Males from infertility } \\
\text { clinic }\end{array}$ & 32 & $108.5 \mu \mathrm{g} / \mathrm{mL}$ & No association & Jurewicz et al. (26) \\
\hline MEHP & Cross-sectional & $\begin{array}{l}269 \text { Males from infertility } \\
\text { clinic }\end{array}$ & 32 & $18.4 \mu \mathrm{g} / \mathrm{mL}$ & $\downarrow$ Motility & Jurewicz et al. (26) \\
\hline MMP & Cross-sectional & $\begin{array}{l}168 \text { Male partners of } \\
\text { sub-fertile couples }\end{array}$ & 36 & $7.5 \mathrm{ng} / \mathrm{mL}$ & $\downarrow$ Morphology & Duty et al. (23) \\
\hline MMP & Cross-sectional & $\begin{array}{l}463 \text { Male partners of } \\
\text { sub-fertile couple }\end{array}$ & 36 & $3.6 \mathrm{ng} / \mathrm{mL}$ & No association & Hauser et al. (24) \\
\hline MMP & Cross-sectional & $\begin{array}{l}45 \text { Male partners of sub-fertile } \\
\text { couples }\end{array}$ & 35 & $1.1 \mathrm{ng} / \mathrm{mL}$ & No association & Wirth et al. (25) \\
\hline MCPP & Cross-sectional & $\begin{array}{l}45 \text { Male partners of sub-fertile } \\
\text { couples }\end{array}$ & 35 & $2.5 \mathrm{ng} / \mathrm{mL}$ & $\downarrow$ Morphology & Wirth et al. (25) \\
\hline BPA & Cross-sectional & 190 Male from infertility clinic & 36 & $1.3 \mathrm{ng} / \mathrm{mL}$ & $\begin{array}{l}\downarrow \text { Concentration, } \\
\text { motility, morphology }\end{array}$ & Meeker et al. (27) \\
\hline BPA & Cross-sectional & $\begin{array}{l}375 \text { Male partners of } \\
\text { pregnant women }\end{array}$ & $32(18-53)$ & $1.5 \mu \mathrm{g} / \mathrm{L}$ & No association & Mendiola et al. $(28,29)$ \\
\hline
\end{tabular}


Table 1 | Continued

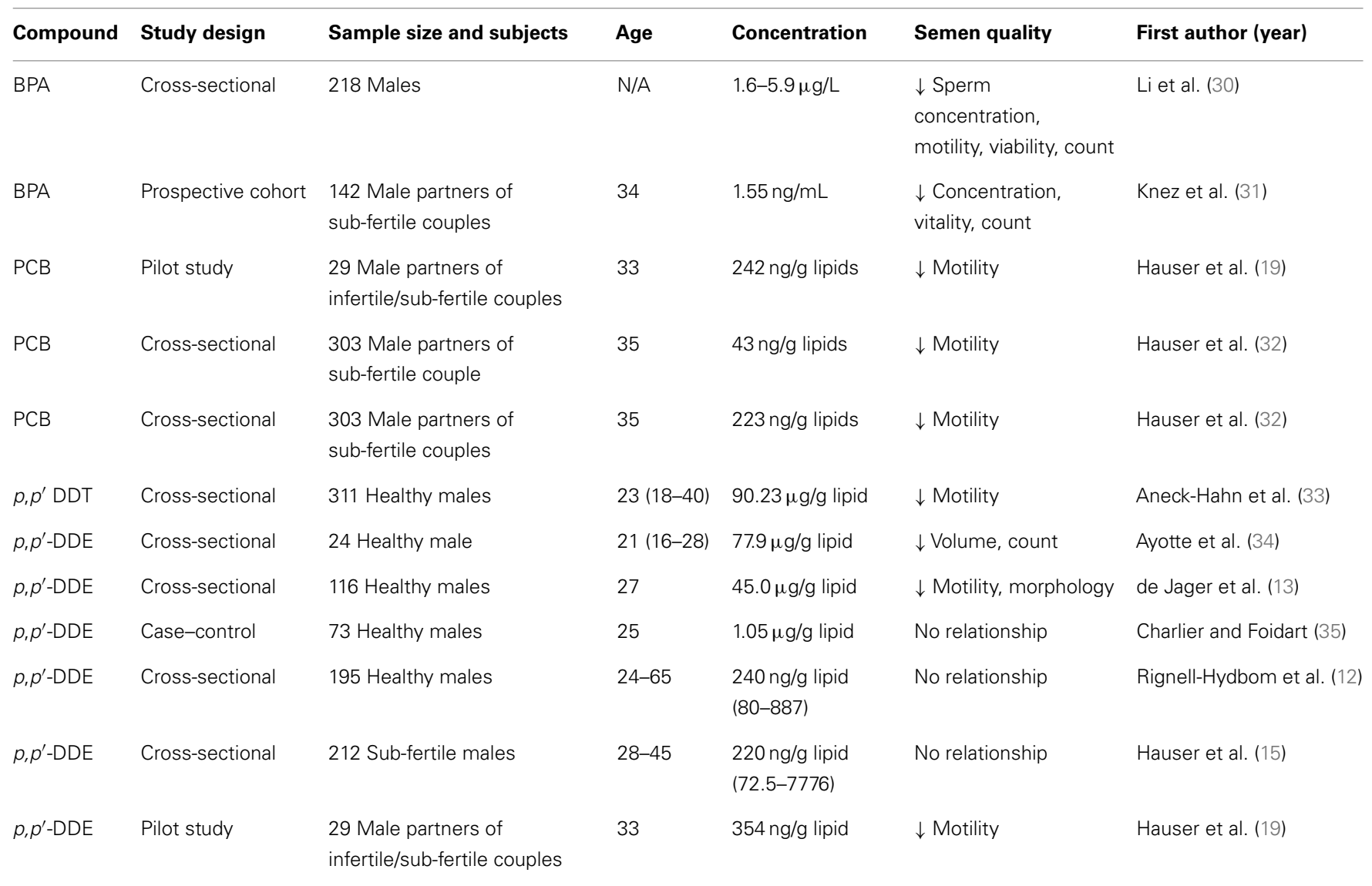

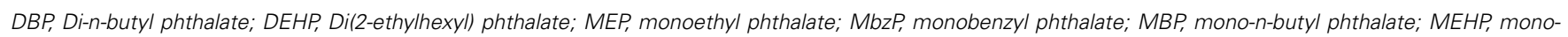

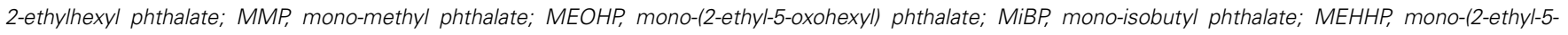
hydroxyhexyl) phthalate; MCPP, mono-(3-carboxypropyl) phthalate, N/A, no data available.

the same time, some have not proven this connection to phthalate metabolites (MBP or MBzP) (50). The aforementioned studies have many important differences, including the age range of the study populations, healthy status of the study populations, differences in the analytical methods used to measure phthalates, adjustment for covariance, and exposure concentrations.

\section{DNA INTEGRITY}

Sperm DNA integrity represents an essential requirement for the accurate transmission of genetic information. The origin of human sperm DNA damage involves certain mechanisms, including (1) alterations in chromatin modeling during the process of spermiogenesis, (2) apoptosis, and (3) oxidative stress (51). Sperm DNA damage has been characterized using the Comet assay (39), the sperm chromatin structure assay (SCSA) (52), and terminal deoxynucleotidyl transferase-driven dUTP nick end labeling (TUNEL) assay (53). Methods assessing sperm DNA integrity have implications and applications for being a better predictor of both in vivo and in vitro fertility than the WHO sperm parameters (54).

There is limited and contradictory epidemiological evidence on whether PCBs can affect human sperm DNA (39, 52, 55). PCBs positively associated with percentage of DNA fragmentation analyzed by the TUNEL assay and the neutral Comet assay (20). Hauser et al. observed no statistically significant consistent associations between the Comet assay parameters and any of the individual PCB congeners or sum of PCBs (39). Reasons for this inconsistency might be different methodologies used to detect sperm DNA damage, varying exposure ranges to and mixtures of persistent organic compounds, and different inclusion criteria for the studies.

Spanò et al. studied whether $p, p^{\prime}$-DDE was associated with altered sperm chromatin integrity among European men. They found no significant associations between $p, p^{\prime}$-DDE serum concentrations and sperm chromatin integrity analyzed by the SCSA (41). A following study conducted by Stronati et al. also observed no correlation between $p, p^{\prime}$-DDE and sperm DNA fragmentation of 652 adult Inuits. A study of a population of Mexican men exposed to a mean concentration of 45,000 ng/g lipid from DDT sprayed in the environment show that impaired sperm chromatin condensation was observed in $46.6 \%$ of participants (13). Another study that was characterized by a mean $p, p^{\prime}$-DDE level of $90,230 \mathrm{ng} / \mathrm{g}$ for DDT reported $54.7 \%$ of the studied young men had impaired sperm chromatin condensation. The percentage of damaged sperm chromatin structure measured by the flow cytometric method had a weak, but positive relationship with 
Table 2 | Epidemiological studies on DNA integrity and endocrine disruptors including phthalates, BPA, PCB, and DDT/DDE.

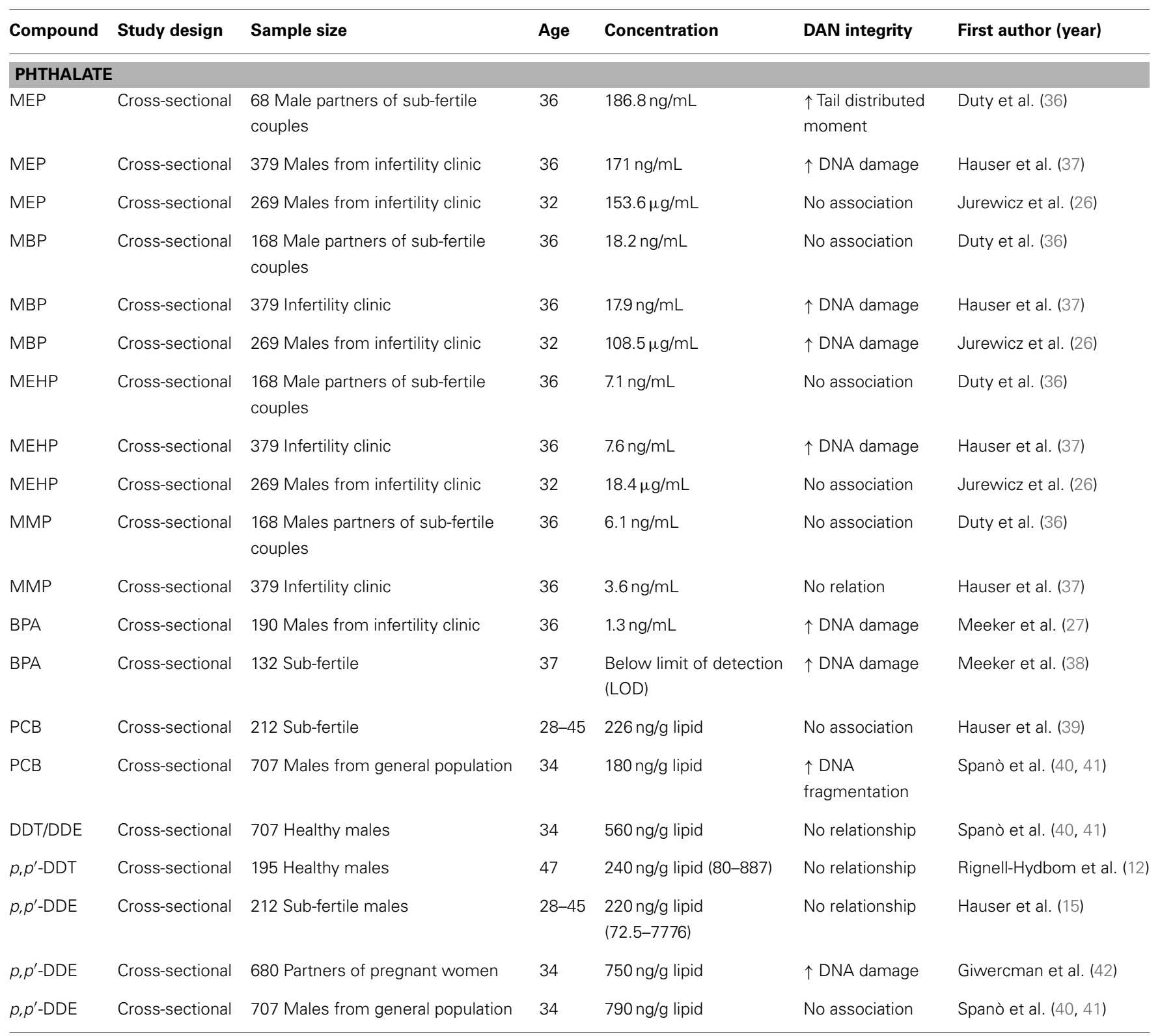

DDT concentrations. However, the percentage of DNA damage and sperm chromatin structure defects were not correlated (56). The finding was in agreement with other studies $(40,52)$. Some epidemiological studies did not find any significant association between DDT/DDE exposure and human sperm DNA (39, 52, 53). However, all of the preceding studies were characterized by a relatively low level of exposure to DDT, as detected by the plasma analysis of DDE, and where the main route of exposure to DDT was through diet. Those studies suggested that additional factors (e.g., genetic background, lifestyle habits, characterization of actual DDT mixture, and their xenohormonal activities) need to be investigated in the future for a better understanding of the effect of DDT exposure on sperm DNA integrity.

A few studies with cellular models indicated that BPA has the potential to induce point mutation, double stranded DNA breaks, and aneuploidy (57, 58; Table 2). Human studies of BPA exposure and sperm DNA damage have been very limited. Meeker et al. assessed the relationship between urinary BPA concentrations and sperm DNA damage in men recruited through a United States infertility clinic. BPA has been associated with increased single-strand breaks of sperm DNA damage among men. Since the studied population was recruited through an infertility clinic, there is a limitation on the ability to generalize the results to the general population $(27,59)$. Another follow-up study investigating relationships between urinary concentrations of parabens and BPA and male reproductive health reported that both parabens and BPA were both positively associated with sperm DNA damage. The study did not reach conclusions regarding causal relationships due to the cross-sectional design (38). 
Limited animal and epidemiologic data exist on the potential general population effects of phthalate exposure on sperm DNA integrity. In a US study, an association between increased sperm DNA damage and MEP was found, but there were no associations with the other phthalate monoesters (36; Table 2). A follow-up study with a larger sample of men and measurement of two oxidative metabolites of DEHP reported consistent evidence of the previous findings that MEP, a metabolite of diethyl phthalate, was associated with increased DNA damage and MEHP, a metabolite of DEHP, was associated with DNA damage after adjustment for the oxidative DEHP metabolites (37). When analyzing six urinary phthalate metabolites from 344 men with normal semen concentrations $(20-300 \mathrm{mln} / \mathrm{mL})$ or slight oligozoospermia (15$20 \times 10^{6} / \mathrm{mL}$ ), Jurewicz et al. reported that urinary MBP levels were significantly associated with an increase in sperm DNA damage (26). The same research group extended the preliminary study by including a large sample of men and measurements of more phthalate metabolites MEHP and MEOHP, two oxidative metabolites of DEHP. Sperm DNA damage was associated with MEHP after adjusting for DEHP oxidative metabolites (26). By contrast, a Swedish study did not find associations between any of the phthalate monoesters and sperm DNA damage measured with the
SCSA (50). A recent study of 232 general population men from a Reproductive Center in Chongqing, China, showed no association between phthalate metabolites and sperm DNA damage using the alkaline single-cell gel electrophoresis assay (60).

\section{REPRODUCTIVE SYSTEM TRACK}

Two congenital anomalies are included in the definition of the testicular dysgenesis syndrome (TDS): cryptorchidism and hypospadias. Cryptorchidism is the failure of one or both testicles to descend into the scrotum, which likely occurs by 6 months of age (61), thus study designs rely only on diagnosis in the delivery room are sub-optimal. Hypospadias, the condition in which the opening of the urethra is on the ventral side of the penis rather than that at the tip of the glans penis, can be diagnosed reliably at birth. Hypospadias may arise during the first trimester of in utero life and is classified as mild (first degree) to severe (third degree), depending on where the urethra opens on the penis. Eight studies have examined the relationship between cryptorchidism and/or hypospadias and DDT and/or metabolites of DDT. Table 3 summarizes results from limited published studies that have examined the association between PCBs and DDT and either cryptorchidism or hypospadias. Two case-control studies

Table 3 | Case-control studies on relationships between cryptorchidism and hypospadias and endocrine disruptors including PCB and DDT/DDE.

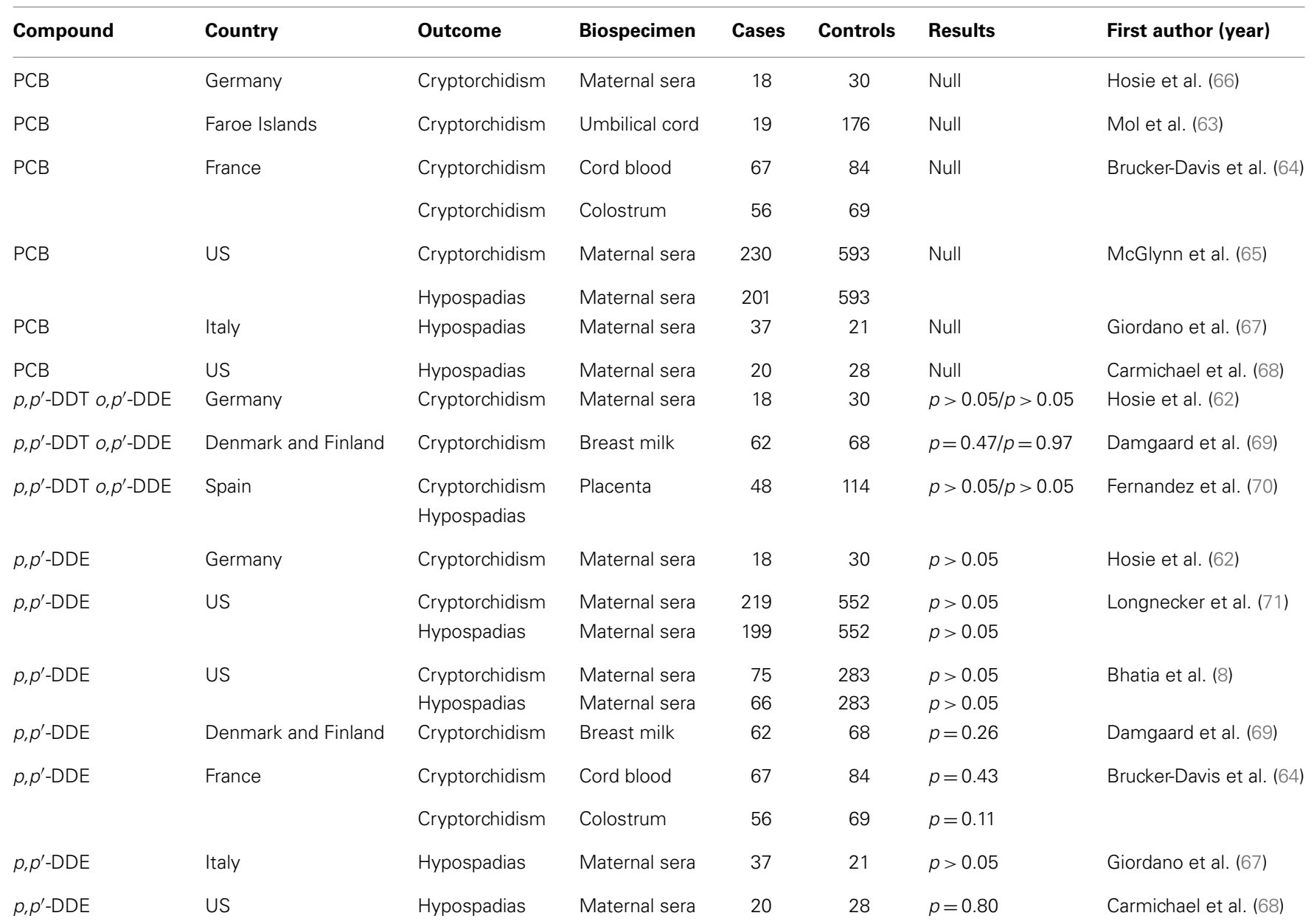


of PCBs and cryptorchidism reported no relationship to risk $(62,63)$, whereas a third offered measured support (64). One ecologic study of PCBs and hypospadias reported an inverse association (42). Because the sample sizes of prior studies may have been too small to detect statistically significant differences, a follow-up study was conducted among a large, well-described population in which the serum samples were collected at a time when PCB levels in the United States were higher. This study analyzed PCBs in the third-trimester serum samples from the mothers of 230 sons with cryptorchidism, 201 sons with hypospadias, and 593 sons with neither condition between 1959 and 1965, and did not strongly support the hypothesis that PCBs are associated with cryptorchidism or hypospadias. Because population serum PCB levels at the time of sample collection were considerably higher than levels at present, it is unlikely that current PCB exposure is related to the development of either anomaly (65).

In a rat model, DBP could prompt changes in testes and male reproductive accessory glands, hypospadias, cryptorchidism, retention of nipples, and reduced anogenital distance $(48,72)$. Studies on laboratory animals have shown that exposure to $500-750 \mathrm{mg}$ of DBP/kilogram during the critical period of male reproductive development results in remarkable phenotypic alterations in normal development (73). At birth, males presented with reduced anogenital distance. In adulthood, the phenotypes included cryptorchidism, epididymal agenesis, testicular atrophy with germ cell loss, hypospadias, and absent or smaller seminal vesicles and prostate (74). In humans, evidence demonstrating a negative action of phthalates on the reproductive tract is also accumulating. A relationship between anogenital distance and maternal urinary concentrations of phthalate metabolites was noted in 85 boys studied by Swan et al. (3). That study investigated the effect of prenatal environmental exposure to phthalates on genital development in newborns.

\section{CANCERS}

Studies investigating an association of DDT with endometrial cancer (75) and prostate and testicular cancer (76) have been inconclusive or do not support an association. Recently, increased exposure to $p, p^{\prime}$-DDE has been reported to associate with risk of both seminomatous and non-seminomatous testicular germ cell tumors (TGCTs) (77). This case-control study investigated pre-diagnostic serum samples from 754 case subjects and 928 control subjects enrolled in the US Servicemen's Testicular Tumor Environmental and Endocrine Determinants (STEED) for DDT exposure. Subjects in the highest serum $p, p^{\prime}$-DDE quartile $(>0.390 \mu \mathrm{g} / \mathrm{g}$ lipid $)$ compared to those in the first serum $p, p^{\prime}$-DDE quartile $(0.157 \mu \mathrm{g} / \mathrm{g}$ lipid) supported increased risk of TGCT in relation to exposure to DDE and PCBs (78). On the other hand, DDE was not associated with TGCT in a case-control study of 876 adult men in Washington State, U.S. (79). Finally, several small studies have suggested an association between PCB exposure and prostate cancer $(80,81)$, whereas no association was reported between PCBs and prostate cancer in a recent Canadian study of 79 cases and 329 age frequency matched controls (82).

As far as genotoxic and mutagenic effects of BPA are concerned, most studies are carried out in in vitro systems, which do not mimic the in vivo environment. BPA has been evaluated in standard screens for mutagenicity including the Ames test, mouse lymphoma, sister chromatid exchange, and mammalian gene mutation assay. Most of the results indicated that BPA is not mutagenic (83). However, some reports have indicated that BPA has the potential to induce point mutation, double stranded DNA breaks, and aneuploidy $(57,58)$. The National Toxicology Program (NTP) has evaluated the carcinogenic activity of BPA and concluded that it was not a robust carcinogen in the context of adult exposure (84). However, careful analysis of the same data documented several shortcoming of the NTP study with respect to effects observed on hematology of mice and testicular tumors, age of animal as well as use of strain of rats and mice and their susceptibility to carcinogenic agents (85). Recent studies have shown that prenatal exposure to BPA causes hyperplasia of prostate in male rats resulting in greater risk of prostate cancer (86). Currently, there are few in vivo genotoxicity studies carried out in bone marrow cells of mice upon BPA exposure at different time intervals (1-5 days), which document that BPA failed to induce chromosomal aberrations and micronuclei formation $(87,88)$. Based on a few in vivo studies, it is impossible to draw a definite conclusion about genotoxic activity of BPA as it is estrogenic in nature.

Most evidence depicting cancer risk associated with exposure to EDC is limited to cellular and animal models. Although some evidence shows associated TGCTs, there is no conclusive evidence to indicate an increased risk of testicular cancer in men exposed to EDCs.

\section{MECHANISM(S) OF ACTION ON EDCs AFFECTING THE MALE REPRODUCTIVE SYSTEM}

Endocrine disrupting chemicals have long been known for their estrogenic properties and the ability to compete with endogenous steroid hormones binding to receptors. EDCs were found to disturb human male steroidogenesis, which alters reproductive hormones, a critical factor in spermatogenesis. Recent studies provide new insights about other mechanisms, such as oxidative stress, genetic susceptibility, and epigenetic effects, related to EDCs' involvement with detrimental reproductive health outcomes.

\section{STEROIDOGENESIS}

Endocrine disrupting chemicals can act as anti-androgens, antiestrogens, and steroidogenic enzyme inhibitors that interfere with steroid action/production as the mechanism to alter male reproductive health. Also, EDCs can interact with thyroid hormones and their receptors or with the brain and the hypothalamo-pituitary axis (89). Certain EDCs could inhibit the enzymes involved in steroidogenesis, which leads to the reduction of hormones. Urinary phthalate metabolites and BPA levels were negatively associated with testosterone levels $(29,90)$, follicle-stimulating hormone (FSH) (91), and luteinizing hormone (LH) (50). Phthalate esters were observed to exert a direct effect on Leydig cell or Sertoli cell structure with correlation of the in vitro and in vivo systems (92). DEHP was also observed to altered Sertoli and Leydig cell function during development and inhibit testosterone production (93). DEHPs can exert their anti-androgenic action by directly inhibiting testosterone synthesis in Leydig cells (94), 
which has been proposed to be a result of cytochrome CYP 17 dysfunction (95). Some phthalates have also been shown to disrupt the patterns of gene expression that regulate cholesterol and lipid homeostasis or insulin signaling, which could also result in lower testosterone synthesis (96). In addition, certain phthalate monoesters may interfere with the ability of Sertoli cells to respond to their normal endogenous ligand of FSH (97). The action site of the phthalate monoester was at the coupling of the FSH receptor-ligand complex to the transducing G-protein within the Sertoli cell membrane (97). Among phthalate metabolites, MEHP did not affect steroidogenesis in the H295R steroidogenesis assay nor alter testosterone production in MA-10 cells $(98,99)$.

Bisphenol A was also observed to have an inverse relationship with reproductive hormones. A recent study showed that the reduction of testosterone could be due to BPA-induced inhibitory effect on the activity of ATP-binding cassette transporters of the cellular membrane of testicular tissues (100). BPA has affinity to bind to estrogen receptors [estrogen receptor alpha $(E R \alpha)$ and estrogen receptor beta $(E R \beta)]$. Knockout models for estrogen receptors have shown that they are the pivotal players required for spermatogenesis, suggesting that estrogen plays an important role in testicular development and spermatogenesis (101).

Dichlorodiphenyltrichloroethane could cause a decrease in transport of testicular androgen as a result of enhanced degradation (102). DDT and its metabolites ( $o, p^{\prime}-\mathrm{DDT}$, and $\left.p, p^{\prime}-\mathrm{DDE}\right)$ can inhibit endogenous ligand binding to the estrogen and androgen receptors. PCBs can disrupt estrogen receptor function by mimicking the natural ligand and acting as an agonist (103).

\section{OXIDATIVE STRESS}

Recent evidence suggests oxidative stress may be one of the mechanisms associated with the effect of phthalates acting as an anti-androgenic compound on male reproductive health. Phthalates, mainly DEHP, DBP, or DEP, have been reported to alter the activities of marker testicular enzymes of laboratory animals associated with the specific events of spermatogenesis, inducing ROS production, lipid peroxidation, and apoptosis of spermatocytes. One possible mechanism is that ROS generation might correlate with DEHP-induced $\mathrm{Ca}^{2+}$ entry, potentially through the $\mathrm{Ca}^{2+}$ mediated activation of the nicotinamide adenine dinucleotide phosphate (NADPH) complex (104). Recently, limited epidemiological studies have also reported that phthalate metabolites are associated with oxidative stress. Fong et al. assessed the association between urinary phthalate metabolites in polyvinyl chloride workers. After adjustment for age, smoking status, and coffee consumption, sperm apoptosis and ROS generation were positively associated with urinary MEHHP, MEOHP, and MEHP (105). Specific signaling pathways mediate increased oxidative stress are needed to confirm oxidative stress as a mechanism for the effect on phthalate.

Bisphenol A could induce oxidative stress in fish spermatozoa in vitro, which results in accumulation of $\mathrm{LO}$ and $\mathrm{CP}$, together with the modification of antioxidant system activity. These oxidative responses were associated with spermatozoa quality depression, as measured by a decrease in the values of spermatozoa motility and velocity (106). Adverse effects of the monomer in male rats may be due to induction of oxidative stress in sperm (107). With limited evidence to date, it is pre-mature to recognize oxidative stress as the mechanism associated with the effect of BPA on male reproductive capacity.

\section{EPIGENETIC MECHANISM}

Possible negative actions on progeny via epigenetic toxic mechanisms have recently been suggested. Epigenetic changes include multiple mechanisms such as DNA methylation, histone modifications, and non-coding RNAs, which regulate gene expression without affecting the gene sequence (108). Epigenetic modifications via DNA methylation are permanent changes, which are transmitted to next generations (109). As indicated earlier, BPA has reduced affinity to bind to estrogen receptors that could lead to gene transcription and regulate DNA methylation in various disease states. Doshi et al. demonstrated that neonatal exposure of rats to BPA led to aberrant DNA methylation in testis, indicating methylation mediated epigenetic changes as one of the possible mechanisms of BPA-induced adverse effects on spermatogenesis and fertility (110). Wu et al. observed that DEHP-induced changes in DNA methylation, especially within $\mathrm{CpG}$ islands, and suggested that changes in DNA methylation may be one possible mechanism of DEHP-mediated testicular toxicity (111). Although emerging observations further expand the possibility of epigenetic as a toxic mechanism of EDCs but are yet to be verified in human studies.

\section{FUTURE RESEARCH NEEDS}

Current evidence has shown variability in study findings regarding the relationship between endocrine disruptors and male reproductive health. Some possibilities explain the variability. First of all, many of the potential exposure-response relationships described here have not been adequately explored. Second, there are differences among the studies, including differences in sample size, study design, study populations, life stage, data analysis approaches, and/or strategies for attaining data on exposure, endpoint, and important covariates. Third, limitations are inherent in epidemiological studies. For example, humans are not exposed exclusively to the chemical being investigated, but instead to a mixture of chemicals, some of them acting through common pathways. In addition, no single compound can act as a surrogate or marker for the others because the contaminant profile varies among individuals. Finally, different chemicals may have different toxicokinetics.

Current evidence has provided a better understanding of the impact of exposure to endocrine disruptors on male reproductive health along with possible mechanisms. However, future studies are needed to address inconclusive outcomes: (1) a well-defined epidemiology study with cohorts of men in various populations is required to evaluate the potential effect of external factors on male reproductive health. Such a study should not be limited to the analysis of sperm concentration, as this may not be the best biomarker of testis function and human fertility; (2) human exposure assessment data does not uniformly support toxicity of the substances at environmental concentrations. There is a need to develop methods to better study mixtures of endocrine disruptors, such as exposure to multiple phthalates at different levels 
and how they may act additively or synergistically, or even antagonistically. Statistical methods should incorporate the biological activity of the different phthalate metabolites, both the monoesters and oxidative metabolites; (3) there is a clear need for chemical and biochemical approaches aimed at a better understanding of the mechanism of action of xenoestrogens with regard to the low-dose effects revealed during developmental exposure. These approaches encompass several areas of study, such as signal transduction via membrane and nuclear ER, and analytical chemistry to measure these chemicals and their metabolites in tissues. Humans are exposed to a variety of endocrine disruptors acting through many different pathways at different times during their development. This poses two problems for consideration: interactions among chemicals acting through a common pathway and a single chemical affecting different pathways. A limited number of studies have shown that certain EDCs could induce epigenetic change. More studies are needed to confirm the results and any association with altered reproductive dysfunction and the etiology of congenital anomalies by identifying tissue-specific genes with changes in DNA methylation; and (4) identify susceptibility factors that may increase risk of adverse effects following exposure to EDCs. Genetic factors may modify the exposure-dose relationship by altering the metabolism or excretion of EDCs. Additionally, genetic factors may modify dose-response relationships by altering the biological response to a given internal dose. More research in this area of susceptibility is critical to our understanding of human health risks.

\section{REFERENCES}

1. Kavlock RJ, Daston GP, DeRosa C, Fenner-Crisp P, Gray LE, Kaattari S, et al. Research needs for the risk assessment of health and environmental effects of endocrine disruptors: a report of the U.S. EPA-sponsored workshop. Environ Health Perspect (1996) 104:715-40. doi:10.1289/ehp.96104s4715

2. Nash JP, Kime DE, Van der Ven LTM, Wester PW, Brion F, Maack G, et al. Long-term exposure to environmental concentrations of the pharmaceutical ethynylestradiol causes reproductive failure in fish. Environ Health Perspect (2004) 112:1725-33. doi:10.1289/ehp.7209

3. Swan SH, Elkin EP, Fenster L. The question of declining sperm density revisited: an analysis of 101 studies published 1934-1996. Environ Health Perspect (2000) 108:961-6. doi:10.1289/ehp.00108961

4. Travison TG, Araujo AB, O’Donnell AB, Kupelian V, McKinlay JB. A population-level decline in serum testosterone levels in American men. J Clin Endocrinol Metab (2007) 92:196-202. doi:10.1210/jc.2006-1375

5. Kania-Korwel I, El-Komy MH, Veng-Pedersen P, Lehmler HJ. Clearance of polychlorinated biphenyl atropisomers is enantioselective in female $\mathrm{C} 57 \mathrm{Bl} / 6$ mice. Environ Sci Technol (2010) 44:2828-35. doi:10.1021/es901781p

6. Norstrom K, Czub G, McLachlan MS, Hu D, Thorne PS, Hornbuckle KC. External exposure and bioaccumulation of PCBs in humans living in a contaminated urban environment. Environ Int (2010) 36:855-61. doi:10.1016/j.envint.2009. 03.005

7. Turusov V, Rakitsky V, Tomatis L. Dichlorodiphenyltrichloroethane (DDT): ubiquity, persistence and risks. Res Rev (2002) 110(2):125-8.

8. Bhatia R, Shiau R, Petreas M, Weintraub JM, Farhang L, Eskenazi B. Organochlorine pesticides and male genital anomalies in the child health and development studies. Environ Health Perspect (2005) 113(2):220-4. doi:10. 1289/ehp.7382

9. Edwards TM, Moore BC, Guillette LJ Jr. Reproductive dysgenesis in wildlife: a comparative view. Int J Androl (2006) 29:109-21. doi:10.1111/j.1365-2605. 2005.00631.x

10. Guillette LJ Jr, Moore BC. Environmental contaminants, fertility, and multioocytic follicles: a lesson from wildlife? Semin Reprod Med (2006) 24:134-41. doi:10.1055/s-2006-944419
11. Kilian E, Delport R, Bornman MS, de Jager C. Simultaneous exposure to low concentrations of DDT, deltamethrin, phytoestrogens and nonylphenol harms reproductive parameters in male rats. Andrologia (2007) 39:128-35. doi:10.1111/j.1439-0272.2007.00777.x

12. Rignell-Hydbom A, Rylander L, Giwercman A, Jönsson BAG, Nilsson-Ehle P, Hagmar L. Exposure to CB-153 and p,p0-DDE and male reproductive function. Hum Reprod (2004) 19:2066-75. doi:10.1093/humrep/deh362

13. de Jager C, Farias P, Barraza-Villarreal A, Avila MH, Ayotte P, Dewailly E, et al. Reduced seminal parameters associated with environmental DDT exposure and p,p0-DDE concentrations in men in Chiapas, Mexico: a cross-sectional study. J Androl (2006) 27:16-27. doi:10.2164/jandrol.05121

14. Toft G, Rignell-Hydbom A, Tyrkiel E, Shvets M, Giwercman A, Lindh CH, et al. Semen quality and exposure to persistent organochlorine pollutants. Epidemiology (2006) 17:450-8. doi:10.1097/01.ede.0000221769.41028.d2

15. Hauser R, Chen Z, Pothier L, Ryan L, Altshul L. The relationship between human semen parameters and environmental exposure to polychlorinated biphenyls and p,p'-DDE. Environ Health Perspect (2003) 111(12):1505-11. doi:10.1289/ehp.6175

16. Biles JE, McNeal TP, Begley TH, Hollifield HC. Determination of bisphenol-A in reusable polycarbonate food-contact plastics and migration to food simulating liquids. J Agric Food Chem (1997) 45:3541-4. doi:10.1021/jf970072i

17. Agency for Toxic Substances \& Disease Registry (ATSDR). Toxicological Profile for Di(2-Ethylnexyl) Phthalate (DEHP). Washington, DC: U.S. Department of Health and Human Services (2002).

18. Aly HA, Domenech O, Abdel-Naim AB. Aroclor 1254 impairs spermatogenesis and induces oxidative stress in rat testicular mitochondria. Food Chem Toxicol (2009) 47:1733-8. doi:10.1016/j.fct.2009.03.019

19. Hauser R, Altshul L, Chen Z, Ryan L, Overstreet J, Schiff I, et al. Environmental organochlorines and semen quality: results of a pilot study. Environ Health Perspect (2002) 110:229-33. doi:10.1289/ehp.02110229

20. Bonde JP, Toft G, Rylander L, Rignell-Hydbom A, Giwercman A, Spano M, et al. Fertility and markers of male reproductive function in Inuit and European populations spanning large contrasts in blood levels of persistent organochlorines. Environ Health Perspect (2008) 116:269-77. doi:10.1289/ehp.10700

21. Pant N, Manju S, Kumar Patel D, Shukla Y, Mathur N, Kumar Gupta Y, et al. Correlation of phthalate exposures with semen quality. Toxicol Appl Pharmacol (2008) 231(1):112-6. doi:10.1016/j.taap.2008.04.001

22. Pant N, Pant AB, Shukla M, Mathur N, Gupta YK, Saxena DK. Environmental and experimental exposure of phthalate esters: the toxicological consequence on human sperm. Hum Exp Toxicol (2011) 30(6):507-14. doi:10.1177/0960327110374205

23. Duty SM, Silva MJ, Barr DB, Brock JW, Ryan L, Chen Z, et al. Phthalate exposure and human semen parameters. Epidemiology (2003) 14:269-77. doi:10.1097/01.EDE.0000059950.11836.16

24. Hauser R, Meeker JD, Duty S, Silva MJ, Calafat AM. Altered semen quality in relation to urinary concentrations of phthalate monoester and oxidative metabolites. Epidemiology (2006) 17:682-91. doi:10.1097/01.ede.0000235996. 89953.d7

25. Wirth JJ, Rossano MG, Potter R, Puscheck E, Daly DC, Paneth N, et al. A pilot study associating urinary concentrations of phthalate metabolites and semen quality. Syst Biol Reprod Med (2008) 54(3):143-54. doi:10.1080/ 19396360802055921

26. Jurewicz J, Radwan M, Sobala W, Ligocka D, Radwan P, Bochenek M, et al. Human urinary phthalate metabolites level and main semen parameters, sperm chromatin structure, sperm aneuploidy and reproductive hormones. Reprod Toxicol (2013) 42:232-41. doi:10.1016/j.reprotox.2013.10.001

27. Meeker JD, Ehrlich S, Toth TL, Wright DL, Calafat AM, Trisini AT, et al. Semen quality and sperm DNA damage in relation to urinary bisphenol A among men from an infertility clinic. Reprod Toxicol (2010) 30:532-9. doi:10.1016/j.reprotox.2010.07.005

28. Mendiola J, Jørgensen N, Andersson AM, Calafat AM, Ye X, Redmon JB, et al. Are environmental levels of bisphenol A associated with reproductive function in fertile men? Environ Health Perspect (2010) 118:1286-91. doi:10.1289/ehp.1002037

29. Mendiola J, Jørgensen N, Andersson A, Calafat A, Silva M, Redmon J, et al. Associations between urinary metabolites of di(2-ethylhexyl)phthalate and reproductive hormones in fertile men. Int J Androl (2010) 14:1-10. doi:10.1111/j.1365-2605.2010.01095.x 
30. Li DK, Zhou Z, Miao M, He Y, Wang J, Ferber J, et al. Urine bisphenol-A (BPA) level in relation to semen quality. Fertil Steril (2011) 95(2):625-30. doi:10.1016/j.fertnstert.2010.09.026

31. Knez J, Kranvogl R, Breznik BP, Voncina E, Vlaisavljevic V. Are urinary bisphenol A levels in men related to semen quality and embryo development after medically assisted reproduction? Fertil Steril (2013) 101(1):215.e-21.e. doi:10.1016/j.fertnstert.2013.09.030

32. Hauser R, Williams P, Altshul L, Calafat AM. Evidence of interaction between polychlorinated biphenyls and phthalates in relation to human sperm motility. Environ Health Perspect (2005) 113(4):425. doi:10.1289/ehp.7305

33. Aneck-Hahn NH, Schulenburg GW, Bornman MS, Farias P, de Jager C. Impaired semen quality associated with environmental DDT exposure in young men living in a malaria area in the Limpopo Province, South Africa. J Androl (2007) 28:423-34. doi:10.2164/jandrol.106.001701

34. Ayotte P, Giroux S, Dewailly E, Hernández Avila M, Farias P, Danis R, et al. DDT spraying for malaria control and reproductive function in Mexican men. Epi (2001) 12(3):366-7.

35. Charlier CJ, Foidart JM. Comparative study of dichlorodiphenyldichloroethylene in blood and semen of two young male populations: lack of relationship to infertility, but evidence of high exposure of the mothers. Reprod Toxicol (2005) 20(2):215-20.

36. Duty SM, Singh NP, Silva MJ, Barr DB, Brock JW, Ryan L, et al. The relationship between environmental exposures to phthalates and DNA damage in human sperm using the neutral comet assay. Environ Health Perspect (2003) 111:1164-9. doi:10.1289/ehp.5756

37. Hauser R, Meeker JD, Singh NP, Silva MJ, Ryan L, Duty S, et al. DNA damage in human sperm is related to urinary levels of phthalate monoester and oxidative metabolites. Hum Reprod (2007) 22(3):688-95. doi:10.1093/humrep/ del428

38. Meeker JD, Yang T, Ye X, Calafat AM, Hauser R. Urinary concentrations of parabens and serum hormone levels, semen quality parameters, and sperm DNA damage. Environ Health Perspect (2011) 119(2):252-7. doi:10.1289/ehp. 1002238

39. Hauser R, Singh NP, Chen Z, Pothier L, Altshul L. Lack of an association between environmental exposure to polychlorinated biphenyls and p,p'-DDE and DNA damage in human sperm measured using the neutral comet assay. Hum Reprod (2003) 18(12):2525-33. doi:10.1093/humrep/deg508

40. Spanò M, Seli E, Bizzaro D, Manicardi GC, Sakkas D. The significance of sperm nuclear DNA strand breaks on reproductive outcome. Curr Opin Obstet Gynecol (2005) 17:255-60. doi:10.1097/01.gco.0000169102.77504.66

41. Spanò M, Toft G, Hagmar L, Eleuteri P, Rescia M, Rignell-Hydbom A, et al. Exposure to PCB and p, p'-DDE in European and Inuit populations: impact on human sperm chromatin integrity. Hum Reprod (2005) 20(12):3488-99. doi:10.1093/humrep/dei297

42. Giwercman YL, Kleist KE, Giwercman A, Giwercman C, Toft G, Bonde JP, et al. Remarkably low incidence of hypospadias in Greenland despite high exposure to endocrine disrupters: possible protective effect of androgen receptor genotype. Pharmacogenet Genomics (2006) 16(5):375-7. doi:10.1097/01.fpc. 0000199497.01101 .93

43. Al-Hiyasat AS, Darmani H. In vivo effects of BISGMA-a component of dental composite-on male mouse reproduction and fertility. J Biomed Mater Res A (2006) 78:66-72. doi:10.1002/jbm.a.30667

44. Furuya M, Adachi K, Kuwahara S, Ogawa K, Tsukamoto Y. Inhibition of male chick phenotypes and spermatogenesis by bisphenol-A. Life Sci (2006) 78:1767-76.

45. Xiao GB, Wang RY, Cai YZ, He GH, Zhou ZJ. Effect of bisphenol A on semen quality of exposed workers: a pilot study. Zhonghua Lao Dong Wei Sheng Zhi Ye Bing Za Zhi (2009) 27(12):741-3.

46. Srivastava S, Singh GB, Srivastava SP, Seth PK. Testicular toxicity of di-n-butyl phthalate in adult rats: effect on marker enzymes of spermatogenesis. Indian J Exp Biol (1990) 28:67-70.

47. Park JD, Sultan SMH, Klaassen CD. Testicular toxicity of di-(2 ethylhexyl) phthalate in young Sprague-Dawley rats. Toxicology (2002) 171:105-15. doi: 10.1016/S0300-483X(01)00567-4

48. Duty S, Calafat AM, Silva MJ, Brock JW, Ryan L, Chen Z, et al. The relationship between environmental exposure to phthalates and computer-aided sperm analysis motion parameters. J Androl (2004) 25(2):293-302.
49. Hauser R, Sergeyev O, Korrick S, Lee MM, Revich B, Gitin E, et al. Association of blood lead levels with onset of puberty in Russian boys. Environ Health Perspect (2008) 116:976-80. doi:10.1289/ehp.10516

50. Jönsson AG, Richthoff J, Rylande L, Giwercman A, Lars H. Urinary phthalate metabolites and biomarkers of reproductive function in young men. Epidemiology (2005) 16(4):487-93. doi:10.1097/01.ede.0000164555.19041.01

51. Aitken RJ, De Iuliis GN. On the possible origins of DNA damage in human spermatozoa. Mol Hum Reprod (2010) 16:3-13. doi:10.1093/molehr/gap059

52. Rignell-Hydbom A, Rylander L, Giwercman A, Jönsson BA, Lindh C, Eleuteri P, et al. Exposure to PCBs and p,p'-DDE and human sperm chromatin integrity. Environ Health Perspect (2005) 113:175-9. doi:10.1289/ehp.7252

53. Stronati A, Manicardi GC, Cecati M, Bordicchia M, Ferrante L, Spanò M, et al. Relationships between sperm DNA fragmentation, sperm apoptotic markers and serum levels of CB-153 and p,p'-DDE in European and Inuit populations. Reproduction (2006) 132(6):949-58. doi:10.1530/rep.1.01034

54. Bungum M, Humaidan P, Axmon A, Spanó M, Bungum L, Erenpreiss J, et al. Sperm DNA integrity assessment in prediction of assisted reproduction technology outcome. Hum Reprod (2007) 22:174-9. doi:10.1093/humrep/ del326

55. Rozati R, Reddy PP, Reddanna P, Mujtaba R. Role of environmental estrogens in the deterioration of male factor fertility. Fertil Steril (2002) 78:1187-94. doi:10.1016/S0015-0282(02)04389-3

56. de Jager C, Aneck-Hahn NH, Bornman MS, Farias P, Leter G, Eleuteri P, et al. Sperm chromatin integrity in DDT-exposed young men living in a malaria area in the Limpopo Province, South Africa. Hum Reprod (2009) 24(10):2429-38. doi:10.1093/humrep/dep249

57. Takahashi S, Chi XJ, Yamaguchi Y, Suzuki H, Sugaya S, Kita K. Mutagenicity of bisphenol $1 \mathrm{~A}$ and its suppression by interferon-alpha in human RSa cells. Mutat Res (2001) 490:199-207. doi:10.1016/S1383-5718(00)00161-3

58. Iso T, Watanabe T, Iwamoto T, Shimamoto A, Furuichi Y. DNA damage caused by bisphenol A and estradiol through estrogenic activity. Biol Pharm Bull (2006) 29:206-10.

59. Meeker JD, Calafat AM, Hauser R. Urinary bisphenol A concentrations in relation to serum thyroid and reproductive hormone levels in men from an infertility clinic. Environ Sci Technol (2010) 44:1458-63. doi:10.1021/es9028292

60. Han X, Cui Z, Zhou N, Ma M, Li L, Li Y, et al. Urinary phthalate metabolites and male reproductive function parameters in Chongqing general population, China. Int J Hyg Environ Health (2014) 217(2-3):271-8. doi:10.1016/j.ijheh. 2013.06.006

61. Hutson JM, Balic A, Nation T, Southwell B. Cryptorchidism. Semin Pediatr Surg (2010) 19(3):215-24. doi:10.1053/j.sempedsurg.2010.04.001

62. Hosie S, Loff S, Witt K, Niessen K, Waag KL. Is there a correlation between organochlorine compounds and undescended testes? Eur J Pediatr Surg (2000) 10(5):304-9. doi:10.1055/s-2008-1072381

63. Mol NM, Sorensen N, Weihe P, Andersson AM, Jorgensen N, Skakkebaek NE, et al. Spermaturia and serum hormone concentrations at the age of puberty in boys prenatally exposed to polychlorinated biphenyls. Eur J Endocrinol (2002) 146:357-63. doi:10.1530/eje.0.1460357

64. Brucker-Davis F, Wagner-Mahler K, Delattre I, Ducot B, Ferrari P, Bongain A, et al. Cryptorchidism at birth in Nice area (France) is associated with higher prenatal exposure to PCBs and DDE, as assessed by colostrum concentrations. Hum Reprod (2008) 23(8):1708-18. doi:10.1093/humrep/den 186

65. McGlynn KA, Guo X, Graubard BI, Brock JW, Klebanoff MA, Longnecker MP. Maternal pregnancy levels of polychlorinated biphenyls and risk of hypospadias and cryptorchidism in male offspring. Environ Health Perspect (2009) 117(9):1472-6. doi:10.1289/ehp.0800389

66. Hosie S, Loff S, Witt K, Niessen K, Waag KL. Is there a correlation between organochlorine compounds and undescended testes? Eur J Pediatr Surg (2000) 10(5):304-9.

67. Giordano F, Abballe A, De Felip E, di Domenico A, Ferro F, Grammatico P, et al. Maternal exposures to endocrine disrupting chemicals and hypospadias in offspring. Birth Defects Res A Clin Mol Teratol (2010) 88:241-50. doi:10.1002/bdra.20657

68. Carmichael SL, Herring AH, Sjodin A, Jones R, Needham L, Ma C, et al. Hypospadias and halogenated organic pollutant levels in maternal midpregnancy serum samples. Chemosphere (2010) 80:641-6. doi:10.1016/j. chemosphere.2010.04.055 
69. Damgaard IN, Skakkebaek NE, Toppari J, Virtanen HE, Shen H, Schramm KW, et al. Persistent pesticides in human breast milk and cryptorchidism. Environ Health Perspect (2006) 114:1133-8. doi:10.1289/ehp.8741

70. Fernandez MF, Olmos B, Granada A, Lopez-Espinosa MJ, Molina-Molina JM, Fernandez JM, et al. Human exposure to endocrine-disrupting chemicals and prenatal risk factors for cryptorchidism and hypospadias: a nested case-control study. Environ Health Perspect (2007) 115(1):8-14. doi:10.1289/ ehp.9351

71. Longnecker MP, Klebanoff MA, Brock JW, Zhou H, Gray KA, Needham LL, et al. Maternal serum level of 1,1-dichloro-2,2-bis(p-chlorophenyl)ethylene and risk of cryptorchidism, hypospadias, and polythelia among male offspring. Am J Epidemiol (2002) 155:313-22. doi:10.1093/aje/155.4.313

72. Lyche JL, Gutleb AC, Bergman A, Eriksen GS, Murk AJ, Ropstad E, et al. Reproductive and developmental toxicity of phthalates. J Toxicol Environ Health B Crit Rev (2009) 12(4):225-49. doi:10.1080/10937400903094091

73. Mylchreest E, Wallace DG, Cattley RC, Foster PMD. Dose-dependent alterations in androgen-regulated male reproductive development in rats exposed to di(n-butyl) phthalate during late gestation. Toxicol Sci (2000) 55:143-51. doi:10.1093/toxsci/55.1.143

74. Parks LG, Ostby JS, Lambright CR, Abbott BD, Klinefelter GR, Barlow NJ, et al. The plasticizer diethylhexyl phthalate induces malformations by decreasing fetal testosterone synthesis during sexual differentiation in the male rat. Toxicol Sci (2000) 58:339-49. doi:10.1093/toxsci/58.2.339

75. Weiderpass E, Adami HO, Baron JA, Wicklund-Glynn A, Aune M, Atuma S, et al. Organochlorines and endometrial cancer risk. Cancer Epidemiol Biomarkers Prev (2000) 9(5):487-93.

76. Ritchie JM, Vial SL, Fuortes LJ, Guo H, Reedy VE, Smith EM. Organochlorines and risk of prostate cancer. J Occup Environ Med (2003) 45(7):692-702. doi:10.1097/01.jom.0000071510.96740.0b

77. McGlynn KA, Quraishi SM, Graubard BI, Weber JP, Rubertone MV, Erickson RL. Persistent organochlorine pesticides and risk of testicular germ cell tumors. J Natl Cancer Inst (2008) 100(9):663-71. doi:10.1093/jnci/ $\operatorname{djn} 101$

78. Purdue MP, Engel LS, Langseth H, Needham LL, Andersen A, Barr BD, et al. Prediagnostic serum concentrations of organochlorine compounds and risk of testicular germ cell tumors. Environ Health Perspect (2009) 117(10):1514-9. doi:10.1289/ehp.0800359

79. Biggs ML, Davis MD, Eaton DL, Weiss NS, Barr DB, Doody DR, et al. Serum organochlorine pesticide residues and risk of testicular germ cell carcinoma: a population-based case-control study. Cancer Epidemiol Biomarkers Prev (2008) 17:2012-8. doi:10.1158/1055-9965.EPI-08-0032

80. Hardell L, Andersson SO, Carlberg M, Bohr L, van Bavel B, Lindstorm G, et al. Adipose tissue concentrations of persistent organic pollutants and the risk of prostate cancer. J Occup Environ Med (2006) 48:700-7. doi:10.1097/01.jom. 0000205989.46603 .43

81. Ritchie JM, Vial SL, Fuortes LJ, Robertson LW, Guo H, Reedy VE, et al. Comparison of proposed frameworks for grouping polychlorinated biphenyl congener data applied to a case-control pilot study of prostate cancer. Environ Res (2005) 98(1):104-13. doi:10.1016/j.envres.2004.05.013

82. Aronson KJ, Wilson JW, Hamel M, Diarsvitri W, Fan W, Woolcott C, et al. Plasma organochlorine levels and prostate cancer risk. J Expo Sci Environ Epidemiol (2009) 20:434-45. doi:10.1038/jes.2009.33

83. Schrader TJ, Langlois I, Soper K, Cherry W. Mutagenicity of bisphenol A (4,4-isopropylidenediphenol) in vitro: effects of nitrosylation. Teratog Carcinog Mutagen (2002) 22:425-41. doi:10.1002/tcm.10039

84. National Toxicology Program. Carcinogenesis bioassay of bisphenol A (CAS no. 80-05-7) in F344 rats and B6C3F mice (feed study). Natl Toxicol Program Tech Rep Ser (1982) 215:1-116.

85. Keri RA, Ho SM, Hunt PA, Knudsen KE, Soto AM, Prins GS. An evaluation of evidence for the carcinogenic activity of bisphenol. Reprod Toxicol (2007) 24:240-52.

86. Ho SM, Tang WY, Belmonte de Frausto J, Prins GS. Developmental exposure to estradiol and bisphenol A increases susceptibility to prostate carcinogenesis and epigenetically regulates phosphodiesterase type 4 variant 4 . Cancer Res (2006) 66:5624-32. doi:10.1158/0008-5472.CAN-06-0516

87. Naika P, Vijayalaxmib KK. Cytogenetic evaluation for genotoxicity of bisphenol-A in bone marrow cells of Swiss albino mice. Mutat Res (2009) 676:106-12. doi:10.1016/j.mrgentox.2009.04.010
88. Pacchierotti F, Ranaldi R, Eichenlaub-Ritter U, Attia S, Adler ID. Evaluation of a neugenic effects of bisphenol A in somatic and germ cells of the mouse. Mutat Res (2008) 651:64-70. doi:10.1016/j.mrgentox.2007.10.009

89. Amaral Mendes JJ. The endocrine disrupters: a major medical challenge. Food Chem Toxicol (2002) 40(6):781-8. doi:10.1016/S0278-6915(02)00018-2

90. Pan G, Hanaoka T, Yoshimura M, Zhang S, Wang P, Tsukino H, et al. Decreased serum free testosterone in workers exposed to high levels of di-n-butyl phthalate (DBP) and di-2-ethylhexyl phthalate (DEHP): a cross-sectional study in China. Environ Health Perspect (2006) 114(11):1643-8.

91. Duty SM, Calafat AM, Silva MJ, Ryan L, Hauser R. Phthalate exposure and reproductive hormones in adult men. Hum Reprod (2005) 20(3):604-10. doi:10.1093/humrep/deh656

92. Jones HB, Garside DA, Lu R, Roberts JC. The influence of phthalate esters on Leydig cell structure and function in vitro and in vivo. Exp Mol Pathol (1993) 58:179-93. doi:10.1006/exmp.1993.1016

93. Sharpe RM. Hormones and testis development and the possible adverse effects of environmental chemicals. Toxicol Lett (2001) 120:221-32. doi:10.1016/ S0378-4274(01)00298-3

94. Desdoits-Lethimonier C, Albert O, Le Bizec B, Perdu E, Zalko D, Courant F, et al. Human testis steroidogenesis is inhibited by phthalates. Hum Reprod (2012) 27:1451-9. doi:10.1093/humrep/des069

95. Foster PM. Mode of action: impaired fetal Leydig cell function - effects on male reproductive development produced by certain phthalate esters. Crit Rev Toxicol (2005) 35:713-9. doi:10.1080/10408440591007395

96. Barlow NJ, Phillips SL, Wallace DG, Sar M, Gaido KW, Foster PM. Quantitative changes in gene expression in fetal rat testes following exposure to di(n-butyl) phthalate. Toxicol Sci (2003) 73:431-41. doi:10.1093/toxsci/kfg087

97. Heindel JJ, Powell CJ. Phthalate ester effects on rat Sertoli cell function in vitro: effects of phthalate side chain and age of animal. Toxicol Appl Pharmacol (1992) 115:116-23. doi:10.1016/0041-008X(92)90374-2

98. Clewell RA, Campbell JL, Ross SM, Gaido KW, Clewell HJ III, Andersen ME. Assessing the relevance of in vitro measures of phthalate inhibition of steroido-genesis for in vivo response. Toxicol In vitro (2010) 24:327-34. doi:10.1016/j.tiv.2009.08.003

99. Roelofs MJ, Piersma AH, van den Berg M, van Duursen MB. The relevance of chemical interactions with CYP17 enzyme activity: assessment using a novel in vitro assay. Toxicol Appl Pharmacol (2013) 268:309-17. doi:10.1016/j.taap.2013.01.033

100. Dankers AC, Roelofs MJ, Piersma AH, Sweep FC, Russel FG, van den Berg $\mathrm{M}$, et al. Endocrine disruptors differentially target ATP-binding cassette transporters in the blood-testis barrier and affect Leydig cell testosterone secretion in vitro. Toxicol Sci (2013) 136(2):382-91. doi:10.1093/toxsci/kft198

101. Delbes C, Levacher C, Habert R. Estrogen effects on fetal and neonatal testicular development. Reproduction (2006) 132:527-38. doi:10.1530/rep.1.01231

102. Bulger WH, Nuccitelli RM, Kupfer D. Studies on the in vivo and in vitro estrogenic activities of methoxychlor and its metabolites role of hepatic monooxygenase in methoxychlor activation. Biochem Pharmacol (1978) 27:2417-23. doi:10.1016/0006-2952(78)90354-4

103. White R, Jobling S, Hoare SA, Sumpter JP, Parker MG. Environmentally persistent alkylphenolic compounds are estrogenic. Endocrinology (1994) 135:175-82. doi:10.1210/en.135.1.175

104. Palleschi S, Rossi B, Diana L, Silverstroni L. Di(2-ethylhexyl) phthalate stimulates $\mathrm{Ca}^{2+}$ entry, chemotaxis and ROS production in human granulocytes. Toxicol Lett (2009) 187:52-7. doi:10.1016/j.toxlet.2009.01.031

105. Fong JP, Lee FJ, Lu IS, Uang SN, Lee CC. Estimating the contribution of inhalation exposure to di-2-ethylhexyl phthalate for PCV production workers, suing personal air sampling and urinary metabolite monitoring. Int J Hyg Environ Health (2014) 217(1):102-9. doi:10.1016/j.ijheh.2013.04.002

106. Hulak M, Gazo I, Shaliutina A, Linhartova P. In vitro effects of bisphenol A on the quality parameters, oxidative stress, DNA integrity and adenosine triphosphate content in starlet (Acipenser ruthenus) spermatozoa. Comp Biochem Physiol C Toxicol Pharmacol (2013) 158:64-71. doi:10.1016/j.cbpc. 2013.05.002

107. Chitra KC, Latchoumycandane C, Mathur PP. Induction of oxidative stress by bisphenol A in the epididymal sperm of rats. Toxicology (2003) 185:119-27. doi:10.1016/S0300-483X(02)00597-8

108. Li E. Chromatin modification and epigenetic reprogramming in mammalian development. Nat Rev Genet (2002) 3:662-73. doi:10.1038/nrg887 
109. Jirtle RL, Skinner MK. Environmental epigenomics and disease susceptibility. Nat Rev Genet (2007) 8(4):253-62. doi:10.1038/nrg2045

110. Doshi T, Mehta SS, Dighe V, Balasinor N, Vanage G. Hypermethylation of estrogen receptor promoter region in adult testis of rats exposed neonatally to bisphenol A. Toxicology (2011) 289:74-82. doi:10.1016/j.tox.2011.07.011

111. Wu S, Zhu J, LiY, Lin T, Gan L, Yuan X, et al. Dynamic effect of di-2-(ethylhexyl) phthalate on testicular toxicity: epigenetic changes and their impact on gene expression. Int J Toxicol (2010) 29(2):193-200. doi:10.1177/1091581809355488

Conflict of Interest Statement: The author declares that the research was conducted in the absence of any commercial or financial relationships that could be construed as a potential conflict of interest.
Received: 13 March 2014; paper pending published: 06 April 2014; accepted: 12 May 2014; published online: 05 June 2014.

Citation: Jeng HA (2014) Exposure to endocrine disrupting chemicals and male reproductive health. Front. Public Health 2:55. doi: 10.3389/fpubh.2014.00055

This article was submitted to Environmental Health, a section of the journal Frontiers in Public Health.

Copyright (C) 2014 Jeng. This is an open-access article distributed under the terms of the Creative Commons Attribution License (CC BY). The use, distribution or reproduction in other forums is permitted, provided the original author(s) or licensor are credited and that the original publication in this journal is cited, in accordance with accepted academic practice. No use, distribution or reproduction is permitted which does not comply with these terms. 